\title{
O republicanismo em Espinho entre o final da Monarquia e a instauração da República (1908-1910)
}

\author{
Ana Rita Gomes \\ anagomes1014@gmail.com
}

\section{Resumo}

Este artigo visa explorar o republicanismo em Espinho no final da Monarquia e a instauração da República, entre os anos de 1908 e 1910. Através da análise da fonte hemerográfica Gazeta de Espinho pretende-se entender a força eleitoral do Partido Republicano Português, em Espinho, nas últimas eleições municipais e paroquiais do tempo da Monarquia, identificando os espaços onde se movimentavam e reconhecendo os principais militantes do partido, bem como a propaganda utilizada para alcançar os votos dos cidadãos espinhenses. Com a queda do regime monárquico, esta investigação pretende estudar a reação do povo de Espinho à mudança de regime e, através da fonte arquivística Atas da Câmara Municipal de Espinho, analisar a transição do poder municipal e as primeiras preocupações e medidas políticas tomadas pela primeira câmara republicana. Dada a relevância da propaganda republicana é, ainda, possível perceber o papel da Gazeta de Espinho - transformada em órgão oficial do PRP - na difusão de novos ideais, criticando o poder monárquico, em defesa do regime republicano.

Palavras-chave: Partido Republicano Português, Republicanismo, Eleições, Propaganda, Monarquia, República, Espinho.

\begin{abstract}
This article aims to explore republicanism in Espinho in the end of the Monarchy and the establishment of the Republic between 1908 and 1910. Through the analysis of the hemerographic source Gazeta de Espinho it is intended to understand the electoral strength of the Portuguese Republican Party, in Espinho, in the last municipal and parish elections during the Monarchy, identifying the spaces to where they moved and recognizing the main militants of the party, as well as the utilized propaganda used to reach the votes of the citizens of Espinho. With the fall of the monarchical regime, this investigation intends to study the people of Espinho reaction to the change of regime and, throughout the arquivistic source Atas da Câmara Municipal de Espinho, analyse the transition of the municipal power and the first concerns and political measures taken by the first republican chamber. Given the relevance of the republican propaganda it is, still, possible to understand the Gazeta de Espinho, role - transformed in oficial department of PRP - in the diffusion of new ideals, criticizing the monarchic power, in defense of the republicanism.
\end{abstract}

Keywords: Portuguese Republican Party, Republicanism, Elections, Propaganda, Monarchy, Republic, Espinho.

\section{Siglas}

PRP - Partido Republicano Português 


\section{Introdução}

O presente trabalho de investigação visa estudar $O$ republicanismo em Espinho entre o final da Monarquia e a instauração da República, entre os anos de 1908 e 1910. Se há muito o republicanismo era alvo de interesse da minha parte, este aumentou quando surgiu a oportunidade de investigar sobre a história de Espinho. Após o contacto com bibliografia relativa a esse período histórico, a abordagem empírica sobre a evolução do republicanismo, em Espinho, foi acompanhada pela análise do órgão oficial do Partido Republicano Português no concelho, a Gazeta de Espinho.

Muitas são as questões interessantes para o conhecimento da evolução do republicanismo em Espinho. Depois de uma leitura atenta da bibliografia, foi possível destacar algumas questões que orientaram na nossa pesquisa. De maneira a identificar os espaços onde se movimentavam os republicanos e a sua organização, assim como os principais «rostos» do partido, impõe-se perguntar de que forma estavam organizados os republicanos de Espinho entre 1908 e 1910. Outrossim, para reconhecer os principais candidatos e a propaganda utilizada para conquistar os votos dos cidadãos espinhenses, questiona-se como evoluiu o Partido Republicano em Espinho desde as eleições municipais e paroquiais de 1908. Apesar da bibliografia esclarecer, sucintamente, a mudança de regime, torna-se relevante aprofundar como ocorreu a implantação da República em Espinho. Na senda desta pergunta, realça-se a tomada de posse pelos membros republicanos e as principais medidas que adotaram. Já em 1907, Joaquim Pinto Coelho, um dos fundadores do periódico, transformou a Gazeta de Espinho em órgão oficial do Partido Republicano. A partir desta altura, assumiu de forma mais clara a difusão de novos ideais, sendo crucial questionar qual foi papel da Gazeta de Espinho na propaganda republicana.

Uma vez que o tema da investigação se insere na história local, a pesquisa bibliográfica levada a cabo partiu de algumas obras relacionadas com a história de Espinho no período em análise. A primeira, A Génese de Espinho - Histórias e Postais, de Carlos Morais Gaio ${ }^{1}$, de 1999, traça a perspetiva e a análise sobre os fatores essenciais do poder político, destacando, sobretudo, o final da Monarquia, a importância do PRP no concelho e a mudança do regime. A segunda obra, Anais da História de Espinho (985-1926), de Francisco Azevedo Brandão², de 1991, trata os principais acontecimentos, personalidades, comemorações e outros aspetos relacionados com a história de Espinho.

\footnotetext{
${ }^{1}$ GAIO, Carlos Morais - A Génese de Espinho. Histórias e Postais. Porto: Campo das Letras, 1999.

${ }^{2}$ BRANDÃO, Francisco Azevedo - Anais da História de Espinho (985-1926). Espinho: CME/JFE, 1991.
} 
Para aprofundar o conhecimento sobre os principais «rostos» do Partido Republicano em Espinho, recorreu-se a dois estudos fundamentais: Exposição - Rostos da República. No âmbito das comemorações do Centenário da República em Espinho (2010), de Ana Amorim³ , e $O$ Nascimento de um Aglomerado Urbano: Espinho no Limiar do Século XX (1998), de António Teixeira Lopes ${ }^{4}$. O primeiro estudo apresenta breves biografias dos principais republicanos do concelho, enquanto o segundo dedica um capítulo a Joaquim Pinto Coelho, o líder do PRP, em Espinho.

Para a contextualização deste período, usou-se também bibliografia geral sobre o final da Monarquia e o início da República, nomeadamente as obras dirigidas por Oliveira Marques 5 , Rui Ramos ${ }^{6}$, por António Telo ${ }^{7}$, por Vasco Pulido Valente ${ }^{8}$ e por Fernando Rosas e Maria Fernanda Rollo 9 .

A principal fonte utilizada foi o semanário Gazeta de Espinho ${ }^{10}$. Trata-se do mais antigo jornal de Espinho. O seu primeiro número foi publicado a 6 de janeiro de 1901. Sendo um jornal informativo, nas duas primeiras páginas publicava notícias de destaque referentes à política nacional e local. A partir de 1909, ao longo de todas as edições, predomina uma secção denominada por «Nota Política». No que concerne à terceira página, prevalece uma secção de expediente, variando o seu título entre «Várias Notícias», «Noticiário» e «Casos e Notícias». Por fim, a quarta página era destinada à publicidade e aos horários de comboio com o respetivo preçário.

A partir de 1902, Joaquim Pinto Coelho, um dos fundadores do jornal e presidente da Câmara de Espinho, começou a tomar posição na disputa do poder, criticando os partidos monárquicos. Mais tarde, em 1905, aderiu ao PRP e, a partir de abril de 1907, a Gazeta de Espinho é transformada em órgão oficial do Partido Republicano no concelho. Num período em que o descrédito da Monarquia Constitucional era cada vez maior, a ideologia republicana expandia-se graças à propaganda difundida pela imprensa periódica.

\footnotetext{
${ }^{3}$ AMORIM, Ana Patrícia Cordeiro de Sousa - Exposição - Rostos da República. No âmbito das comemorações do Centenário da República em Espinho. Porto: FLUP, 2010. Relatório de Estágio de Mestrado em História da Arte.

${ }^{4}$ LOPES, António Teixeira - O Nascimento de um Aglomerado Urbano: Espinho no Limiar do Século XX. Porto: FLUP, 1998. Dissertação de Mestrado em História Contemporânea.

${ }_{5}^{5}$ MARQUES, A. H. de Oliveira (coord.) - "Portugal da Monarquia para a República". In SERRÃO, Joel; MARQUES, A. H. de Oliveira (dir.) - Nova História de Portugal. Vol. XI. Lisboa: Editorial Presença, 1991.

${ }^{6}$ RAMOS, Rui (coord.) - «A Segunda Fundação». In MATTOSO, José (dir.) — História de Portugal, vol. 6. Lisboa: Editorial Estampa, 1997.

${ }^{7}$ TELO, António José - Primeira República I - Do sonho à realidade. Lisboa: Editorial Presença, 2010.

${ }^{8}$ VALENTE, Vasco Pulido - O poder e o povo: a revolução de 1910. Lisboa: Gradiva, 1999.

${ }^{9}$ ROSAS, Fernando; ROLLO, Maria Fernanda (coord.) - História da Primeira República portuguesa. Lisboa: Tinta-da-china, 2009.

${ }^{10}$ Gazeta de Espinho. Espinho, 1901-1932.
} 
Perante a ausência de informação no periódico sobre a constituição da primeira vereação republicana e as suas principais preocupações em termos políticos, foi necessário recorrer a uma fonte arquivística: as Atas da Câmara Municipal de Espinho ${ }^{11}$.

No que concerne às opções metodológicas, a análise intensiva constituiu o método de pesquisa central desta investigação. Para o melhor tratamento dos dados recolhidos produziuse uma base de dados, em Excel, onde se registaram os dados empíricos. Na análise das fontes arquivísticas, as Atas da Câmara Municipal de Espinho, organizámos a informação recolhida em fichas de leitura, em Word, que permitiram sintetizar os aspetos políticos das reuniões. Embora seja predominantemente qualitativa, a nossa análise engloba também a abordagem quantitativa, nomeadamente para a comparação dos votos obtidos nas eleições municipais e paroquiais, pelos republicanos e pelos membros das listas monárquicas, em 1908.

\section{A expansão do republicanismo no final da Monarquia}

Em Portugal, a partir do século XIX, começaram-se a desenhar várias alternativas ao liberalismo monárquico, entre os quais o republicanismo, de cariz democrático. $\mathrm{O}$ início do grande desenvolvimento do PRP - fundado em 1876, como um «pequeno grupo com um programa muito genérico» ${ }^{12}$ - começou ainda em finais do século XIX, mas acentuou-se nos primeiros anos do século XX. Os republicanos consideravam-se os representantes do povo, procurando asseverar que o final da Monarquia resolveria os problemas nacionais. $\mathrm{O}$ pensamento republicano passava, inicialmente, por «um renascimento marcado pela temática da decadência nacional face à Europa, que muitos republicanos atribuíam [...] à influência da Igreja e da Inglaterra $\rangle^{13}$. A partir de 1890 , no contexto do Ultimatum britânico, o PRP assumiu novas ideologias assentes no nacionalismo e patriotismo português ${ }^{14}$.

Num panorama geral de um campo político em mudança e de reivindicações sociais, a ascensão republicana tornou-se inequívoca, essencialmente, desde 1903. Em 1904, «os republicanos discutiram se deveriam disputar eleições» ${ }^{15}$ e, consequentemente, as Comissões Municipais de Lisboa, Porto e Coimbra impuseram uma ação partidária constante nas eleições. Outrossim, o crescimento manteve-se em 1906 e 1907 graças à ação proficiente da Comissão Reorganizadora do partido. A evolução republicana foi expressa, imediatamente, nas eleições legislativas de 1908, com a eleição de sete deputados, distribuídos pelas regiões de Lisboa, Beja

\footnotetext{
${ }^{11}$ Arquivo Municipal de Espinho - Atas da Câmara Municipal de Espinho, 1908-1910.

12 TELO, António José - Primeira República I - Do sonho à realidade, p. 58.

${ }^{13}$ Idem, ibidem.

${ }^{14}$ Idem, ibidem.

${ }^{15}$ ROSAS, Fernando; ROLLO, Maria Fernanda (coord.) - História da Primeira República portuguesa, p. 66.
} 
e Setúbal ${ }^{16}$. Perante a intensa ação partidária, os republicanos conquistavam lugares parlamentares e como membros de Câmaras Municipais ${ }^{17}$. A luta intensa contra João Franco havia mobilizado o campo político e o desenvolvimento republicano acelerou-se até $1910^{18}$.

A imprensa republicana foi uma das armas mais significativas contra o regime monárquico. Nos anos 90 do século XIX, a par das reivindicações sociais, o rotativismo e os seus políticos - considerando-os "atores de um espetáculo indecoroso da divisão da coisa comum"19 - foram duramente criticados pelos republicanos, bem como a legitimidade do rei D. Carlos - "que desejava o engrandecimento do poder real e chamara para o poder João Franco, o ditador" ${ }^{20}$ - e, posteriormente a crítica à «Monarquia Nova» de D. Manuel II, considerada uma "coisa «velha», sem soluções para o país"21. O PRP atraiu a atenção do país ao organizar as celebrações do Centenário de Camões, em 1880, investindo no contacto com as massas populares, enquadradas em grandes comícios. Ao contrário dos partidos monárquicos, o PRP tinha a preocupação de criar à sua volta «uma rede fluida e flexível de organizações de vários tipos, quase todas oficialmente independentes, que enquadravam as massas e permitiam a mobilização política nas alturas apropriadas ${ }^{22}$. Dessarte, a força organização republicana interligava-se com sociedades, clubes e escolas, como a Associação do Registo Civil, a Carbonária, a Liga Republicana das Mulheres Portuguesas e a Maçonaria, associando-se a livres-pensadores, liberais, socialistas, etc. O movimento contava, ainda, com centros de socorro mútuos, de apoio e solidariedade, jornais, grupos de teatros, associações de classe como os lojistas -, coletividades e bandas de música ${ }^{23}$.

A propaganda republicana era feita com notáveis locais, sobretudo através da influência dos médicos e dos comerciantes. Dirigiam-se a toda a gente, mas eram as classes médias quem mais os ouvia ${ }^{24}$. Os médicos eram uma espécie de «padres» da República e, tal como nos demonstra Rui Ramos, “em novembro de 1908, o presidente do Conselho queixava-se: «A propaganda republicana não descansa e faz-se pelos médicos, que são elementos valiosíssimos nas aldeias»" ${ }^{25}$. Efetivamente, o otimismo dos republicanos dominava as freguesias de operários e as campanhas eleitorais demonstravam um extenso trabalho político dos chefes do

\footnotetext{
${ }^{16}$ RAMOS, Rui (coord.) - «A Segunda Fundação», p. 297.

${ }^{17}$ ROSAS, Fernando; ROLLO, Maria Fernanda (coord.) - História da Primeira República portuguesa, p. 65.

${ }^{18}$ Idem, p. 66.

${ }^{19}$ Idem, p. 63.

${ }^{20}$ Idem, ibidem.

${ }^{21}$ Idem, ibidem.

${ }^{22}$ TELO, António José - Primeira República I - Do sonho à realidade, p. 57.

${ }^{23}$ ROSAS, Fernando; ROLLO, Maria Fernanda (coord.) - História da Primeira República portuguesa, p. 69.

${ }^{24}$ Idem, p. 70.

${ }^{25}$ RAMOS, Rui (coord.) - «A Segunda Fundação», p. 300.
} 
partido, orientando a sua propaganda na difusão da sua doutrina, assente no progresso e na ideia de uma sociedade mais democrática ${ }^{26}$.

A infalível campanha republicana contribuiu para uma erosão na Monarquia. Todavia, ressaltam outros fatores. Desde a questão do Ultimatum, em 1890 e as dificuldades do Estado português como potência colonial, a realidade política estava a alterar-se rapidamente. $\mathrm{O}$ rotativismo partidário coincidiu com a multiplicação dos partidos na política portuguesa. Em Portugal, existiam dois grandes partidos parlamentares dirigidos por Hintze Ribeiro e José Luciano $^{27}$. Apesar da tentativa de reorganização do aparelho político, depois de 1908, os partidos monárquicos estavam muito enfraquecidos, a começar pelo Regenerador, uma vez que não conseguia absorver a dissidência franquista (Partido Regenerador Liberal, criado em 1901). Após a morte do seu líder histórico, Hintze Ribeiro - substituído por Júlio de Vilhena - e a ausência de políticas de reformas, o Partido Regenerador entrou numa crise permanente, com a sua direção entregue a personalidades secundárias ${ }^{28}$. O Partido Progressista, chefiado por José de Alpoim - encontrava-se no mesmo estado e, em finais de 1908, dividiu-se em dois blocos: progressistas e dissidentes progressistas. Apesar desta divisão "qualquer dos blocos era incapaz de sair do círculo fechado dos partidos tradicionais e mobilizar as populações" ${ }^{29}$.

Em 1906, a entrada de João Franco para o Governo representava uma abertura à esquerda, revelando a sua intenção de "ficar nos livros como o mais liberal e decidido chefe do governo de sempre" 30 . Todavia, já em setembro do mesmo ano, o Governo nunca foi o que Franco desejava ser e, em 1907, a fusão política com o Partido Progressista havia terminado. Os rotativos colocaram-se na oposição e defendiam o anti franquismo ${ }^{31}$. Desde sempre, João Franco manteve o apoio do rei D. Carlos, mas três dias depois do regicídio, o ministério franquista cedeu lugar a um governo de coligação monárquica, presidido por um independente e com a participação de dois regenerados, dois progressistas e dois independentes ${ }^{32}$. Com o regresso dos rotativos ao poder e a nomeação do almirante Ferreira do Amaral, a política de «acalmação» passava por devolver o poder aos partidos tradicionais, libertar todos os presos pela revolta fracassada de janeiro de 1908 e seguir uma política de cedência e conciliação. O principal propósito de D. Manuel II passava por reformar a Monarquia por dentro, unindo os monárquicos tradicionais à volta do trono e afastando todos os que pretendiam a reforma do

\footnotetext{
${ }^{26}$ ROSAS, Fernando; ROLLO, Maria Fernanda (coord.) - História da Primeira República portuguesa, p. 71.

${ }^{27}$ RAMOS, Rui (coord.) - «A Segunda Fundação», p. 223.

${ }^{28}$ TELO, António José - Primeira República I-Do sonho à realidade, p. 97.

${ }^{29}$ Idem, ibidem.

${ }^{30}$ RAMOS, Rui (coord.) - «A Segunda Fundação», p. 236.

${ }^{31}$ Idem, p. 250.

${ }^{32}$ MARQUES, A. H. de Oliveira (coord.) - "Portugal da Monarquia para a República", p. 694-695.
} 
regime $^{33}$. Contudo, o rei tornou-se ma pessoa em quem ninguém confiava e a quem pouca gente respeitava ${ }^{34}$, afastando os mais sinceros defensores da Monarquia.

O Diretório do Partido Republicano Português aproveitou para se aproximar do poder em Portugal. Nos últimos dois anos da Monarquia, os partidos «históricos» sofreram mais divisões e conflitos internos e, para agravar a situação, em 1910, “os republicanos descobriram uma nova série de «escândalos financeiros» em que andavam comprometidos vários dos grandes caciques progressistas" ${ }^{\text {35 }}$. Em outubro de 1910 - após tantos anos a planear a revolução -, os republicanos preparavam-se para assaltar o poder, através das insurreições revolucionárias nos vários quarteis de Infantaria, Artilharia e Marinha. Na madrugada de 4 de outubro de 1910, os republicanos saíram à rua, promovendo uma ação militar na Rotunda, lançado de dois pontos opostos - do Sul, pelos regimes do Rossio, e do Norte, pelas baterias de Queluz, por Lanceiros 2 e por Infantaria $2^{36}$. A relutância do Exército em lutar era evidente, mas os «homens da Rotunda» "ficaram, antes de mais, porque a única saída era um exílio de miséria e morte [...] Mas ficaram também porque mesmo naquela crise ainda esperavam vencer" ${ }^{37}$. No dia seguinte, a 5 de outubro, "quando o encarregado de Negócios apareceu no Rossio com uma bandeira branca bem à vista das tropas e do povo, todos julgaram que a Monarquia capitulara"38. Uma hora mais tarde, a República foi proclamada no Paços do Concelho e anunciada a constituição do Governo Provisório. A revolução republicana foi feita pelas camadas mais baixas da pequena burguesia.

\section{O republicanismo em Espinho entre o final da Monarquia e a instauração} da República (1908-1910)

\subsection{A organização dos republicanos de Espinho entre 1908 e 1910}

\subsubsection{A organização dos republicanos}

Os republicanos organizavam-se em Comissões - Municipal e Paroquial - convocando reuniões entre os cidadãos eleitores de Espinho.

A primeira reunião do Partido Republicano de Espinho ocorreu no dia 25 de março de 1905, na rua do Cruzeiro, n. ${ }^{\circ}$ 55, onde se realizou uma sessão entre os cidadãos republicanos para proceder à eleição dos membros que deveriam constituir a primeira Comissão Municipal Republicana. Uma vez aberta a sessão, sob a presidência de António dos Santos Pouzada ${ }^{39}$,

\footnotetext{
${ }^{33}$ TELO, António José - Primeira República I - Do sonho à realidade, p. 93-94.

${ }^{34}$ RAMOS, Rui (coord.) - «A Segunda Fundação», p. 309.

${ }^{35}$ VALENTE, Vasco Pulido - O poder e o povo: a revolução de 1910, p. 94.

${ }^{36}$ Idem, p. 105.

${ }^{37}$ Idem, p. 111.

${ }^{38}$ Idem, p. 109.

${ }^{39}$ Em 1908, requereu-se a sua eliminação do cadastro do Partido Republicano Português.
} 
foram nomeados como secretários António de Freitas Salgado ${ }^{40}$ e Artur Gonçalves de Matos, e como escrutinadores José de Bessa de Carvalho e Alberto Delgado. Findo o ato eleitoral, com o apuramento de 15 listas na urna, redigiu-se a ata da organização do Partido Republicano, sendo assinada pelos membros que constituíam a mesa ${ }^{41}$. A partir de então, efetuaram-se eleições para nomear cinco membros e cinco substitutos das respetivas Comissões.

A Comissão Paroquial Republicana, responsável pela reorganização do cadastro partidário, convidava todos os cidadãos espinhenses - que desejassem inscrever-se como eleitores -, a obterem esclarecimentos junto dos correligionários republicanos. Numa época de revisão do recenseamento eleitoral, só podia ser eleitor o cidadão português -, maior de 21 anos (completados até 30 de junho), domiciliados em território nacional, que soubesse ler e escrever ou que estivessem coletados em verba não inferior a 500 réis de uma ou mais contribuições diretas do Estado ${ }^{42}$. Os requerimentos eram entregues na secretaria municipal e deviam ser acompanhados da certidão de idade e do certificado de morada, passado pelo regedor da freguesia ${ }^{43}$.

Reunindo-se na rua do Norte, $\mathrm{n}^{\circ}$ 124, aos domingos, entre as 19 e as 21 horas, a Comissão Municipal Republicana convidava todos os seus correligionários a participarem. As razões políticas para a realização das reuniões eram variadas, destacando-se "a fim de tratar de assuntos eleitorais" 44 e de "assuntos urgentes de organização partidária"45.

\subsubsection{Os principais meios de propaganda política}

O Partido Republicano Português usufruía de vários meios de propaganda política, incidindo, sobretudo, na imprensa, criando e reproduzindo "imagens dos diferentes líderes e principais caudilhos do partido" 46 . Com uma rede fluida de organizações, os republicanos compreenderam o desenraizamento cultural que os milhares de migrantes sentiam, ao sair das suas zonas rurais. A arte dos republicanos "foi a de ter entendido esta grave lacuna e [...] com isto levaram para o ideário republicano [...] os melhores elementos de uma população recentemente chegada às cidades e [...] conseguiram uma influência imensa sobre os outros"47.

Perante a divulgação dos princípios democráticos, a influência da sua ideologia republicana sobre as populações - sobretudo, na classe média - era crescente. Os republicanos

\footnotetext{
${ }^{40}$ António de Freitas Salgado foi despedido no dia seguinte pela Real Fábrica das Conservas, em consequência do seu ato.

41 "História Ata da Organização do Partido Republicano em Espinho". Gazeta de Espinho, n. ${ }^{\circ}$ 509, 18.10.1910, p. 2.

${ }^{42}$ ALMEIDA, Pedro Tavares - Legislação Eleitoral Portuguesa - 1820-1926. Lisboa: Imprensa Nacional, 1998, p. 485.

43 "Recenseamento Eleitoral", Gazeta de Espinho, n. ${ }^{4}$ 413, 13.12.1908, p. 2.

44 “Partido Republicano de Espinho - Reunião Eleitoral”. Gazeta de Espinho, n. ${ }^{\circ} 405,18.10 .1908$, p. 1.

45 “Convite". Gazeta de Espinho, n. ${ }^{\circ} 439,13.06 .1909$, p. 2.

${ }^{46}$ ROSAS, Fernando; ROLLO, Maria Fernanda (coord.) - História da Primeira República portuguesa, p. 71.

47 TELO, António José - Primeira República I - Do sonho à realidade, p. 59.
} 
consideravam que, quando o povo compreendesse o seu valor e estimulasse o sentimento patriótico, eliminando a indiferença, o regime monárquico terminava ${ }^{48}$. Parecia impossível que as ideias democráticas se adaptassem a Portugal, sobretudo no mundo rural, onde o campesinato, analfabeto e muito dependente dos influentes locais e das tradições católicas, temia a instauração da República. Contudo, através da imprensa os republicanos pregavam os seus ideais, afirmando respeitar as crenças habituais:

Hoje, em contraste, a República, pregada pelos seus apóstolos devotados, aparece-lhes ordeira e pacífica, sentimental e educadora, liberal e comedida, cheia de bondade, de justiça, de abnegação [...] a República não é assassina e intolerante, como te mentiam, desgraçado aldeão! A República respeita as tuas crenças, não é inimiga da tua fé, não briga com a tua religião! ${ }^{49}$

Os convites constituíam outro meio de propaganda republicana. Através da Gazeta de Espinho o secretário da Comissão Municipal Republicana, Francisco de Resende, difundia convocatórias para que todos os cidadãos republicanos, residentes em Espinho, se inscrevessem no cadastro que a Comissão Paroquial organizava ${ }^{50}$. Do mesmo modo, apelava-se ao voto nos candidatos republicanos, criticando a corrupção vigente e incentivavam a população a votar nos republicanos para promover a emancipação política, uma vez que todas as instituições e os homens que as assistiam tinham o direito a serem livres. Para além disso, apelavam aos cidadãos que exercessem o direito conquistado nas épocas anteriores, sendo que "abdicar desta regalia ou traí-la é um crime" 51 .

Os republicanos organizavam comícios para difundir a sua ideologia. Em 1908, em Aveiro, no comício realizado entre Lourosa e Fiães, falaram, com grande entusiasmo, figuras ilustres de Espinho, como Joaquim Pinto Coelho, Manuel Laranjeira e Alberto Delgado. Na mesa foram lidas algumas adesões ao Partido Republicano, destacando-se a candidatura de José Bessa de Carvalho como deputado do círculo distrital ${ }^{52}$. Por seu turno, recorriam aos meios publicitários para indiciar a possibilidade de se efetuar uma série de conferências democráticas, no concelho de Espinho ${ }^{53}$. Sem embargo, apesar dos esforços enviados pelos republicanos, perante as dificuldades de realização imediata, as conferências democráticas foram impedidas de se concretizarem. Ainda assim, em 1909, os devotos defensores da República contavam “que muito breve - o que oportunamente se publicará - esse projeto de propaganda seja uma realidade" ${ }^{2}$.

\footnotetext{
48 “A Nossa Propaganda”. Gazeta de Espinho, n. ${ }^{\circ} 377,05.04 .1908$, p. 1.

${ }^{49}$ Idem.

50 "Convite". Gazeta de Espinho, n. 442, 04.07.1909, p. 4.

51 "Eleitores, A'urna pelos candidatos republicanos". Gazeta de Espinho, n. ${ }^{\circ}$ 502, 28.08.1910, p. 2.

52 “Comícios de propaganda no distrito d'Aveiro". Gazeta de Espinho, n. ${ }^{\circ} 377,05.04 .1908$, p. 2.

53 “Convite". Gazeta de Espinho, n. ${ }^{\circ} 442,04.07 .1909$, p. 4.

${ }^{54}$ Idem.
} 
Nos principais hotéis de Espinho optavam por realizar festas democráticas, em homenagem a republicanos de renome. No Grande Hotel realizou-se um jantar comemorativo, reunindo republicanos do concelho de Espinho - amigos e políticos do professor e deputado eleito por Lisboa, o Dr. Alfredo Magalhães -, com o objetivo de enaltecer a sua ação propagandista republicana ${ }^{55}$. Do mesmo modo, no Hotel Bragança teve lugar um almoço em homenagem a José Bessa de Carvalho, realizando-se uma manifestação de simpatia e de apreço pelas suas qualidades de espírito e de caráter $^{56}$. As festas republicanas decorriam com animação e discursos que exaltavam os sentimentos de fraternidade republicana.

\subsubsection{Os espaços onde se movimentavam}

$\mathrm{Na}$ maioria das vezes, o local onde os republicanos promoviam as suas reuniões era o Centro Republicano - Escola António José de Almeida, na rua do Norte, n. ${ }^{\circ}$ 124, fundado por José Bessa de Carvalho ${ }^{57}$. Era aqui que se realizavam as assembleias gerais e as eleições das novas Comissões ${ }^{58}$. Todos os republicanos deveriam comparecer na escola noturna, com o objetivo "de cumprir o dever cívico e disciplina partidária" ${ }^{29}$. Todavia, outros espaços eram utilizados pelos republicanos para as suas atividades. No estabelecimento comercial de Manuel Casal Ribeiro - a Padaria Casal Ribeiro ${ }^{60}$-, tal como na rua do Cruzeiro, n. ${ }^{\circ} 37^{61}$, concretizavam-se as inscrições dos republicanos que desejavam filiar-se no cadastro geral do partido. Só eram considerados republicanos os indivíduos que se inscrevessem no cadastro, pertencentes a Espinho, de acordo com a lei orgânica do PRP. Tal como referido anteriormente, no Grande Hotel de Espinho sucediam-se as festas democráticas ${ }^{62}$, de maneira a prestar homenagem aos republicanos ilustres e a difundir a propaganda republicana.

\subsubsection{Os principais «rostos» do Partido Republicano em Espinho}

Desde logo, nomes como Manuel Laranjeira, Joaquim Pinto Coelho, Bessa de Carvalho e Francisco de Resende aparecem associados como membros da Comissão Municipal Republicana, em Espinho.

Em Espinho não havia, até aos primeiros anos do século XX, uma mesa republicana, nem um movimento democrático. Foi José Bessa de Carvalho que deu o primeiro impulso para

\footnotetext{
55 “Alfredo de Magalhães”. Gazeta de Espinho, n. ${ }^{\circ}$ 505, 18.09.1910, p. 3.

56 “Em honra do Dr. José Bessa de Carvalho". Gazeta de Espinho, n. ${ }^{\circ}$ 511, 06.11.1910, p. 1.

57 "Dr. José Bessa de Carvalho", Gazeta de Espinho, n. ${ }^{\circ}$ 511, 06.11.1910, p. 1.

58 "Partido Republicano". Gazeta de Espinho, n. ${ }^{\circ} 445,25.07 .1909$, p. 1.

59 "Partido Republicano - Eleição". Gazeta de Espinho, n. ${ }^{\circ} 442,04.07 .1909$, p. 4.

60 "Partido Republicano - Avisos". Gazeta de Espinho, n. ${ }^{\circ} 443,17.07 .1909$, p. 1.

61 “Aos Republicanos de Espinho”. Gazeta de Espinho, n. . 509, 18.10.1909, p. 3.

62 “Alfredo Magalhães”. Gazeta de Espinho, n. ${ }^{\circ} 505,18.09 .1910$, p. 3.
} 
a organização do Partido Republicano em Espinho. Nasceu em 1872 na Baía, filho do republicano Joaquim Bessa de Carvalho e de Emília Amélia Cardoso Carvalho. Como advogado ${ }^{63}$ e jornalista dirigiu a Voz Pública e foi proprietário do jornal $O$ Norte $^{64}$. Iniciou a sua intenção educativa, através da fundação de uma escola noturna para adultos: a Escola António José de Almeida. Tal criação exigiu-lhe dinheiro, trabalho e algumas calúnias ${ }^{65}$. O intuito democrático de José Bessa de Carvalho associou-se à realização de um programa para fundar uma escola livre $^{66}$. Para além disso, tomou a deliberação de remodelar ou fundar o Ginásio de Espinho, integrando um pequeno grupo de rapazes que se reunia para promover a atividade física ${ }^{67}$.

Na partida de Bessa de Carvalho para Lisboa, para exercer funções como deputado, Manuel Laranjeira dedicou-lhe uma homenagem, considerando:

E posso garantir-lhe que uma das maiores alegrias do Dr. Bessa de Carvalho foi saber que a Escola António José de Almeida estava sendo finalmente sustentada por subscrição popular, como ele sonhara, ao fundá-la [...]. É, pois, a justa homenagem [...] ao Dr. José Bessa de Carvalho; direi mais - é mesmo uma dívida e gratidão cívica que todos nós lhe devemos. Associo-me a ele de todo o coração e abraço-vos entusiasticamente ${ }^{68}$.

A sua visita a Espinho era frequente, com os seus filhos, Álvaro de Castro Bessa e Alberto de Castro Bessa de Carvalho, seguindo para Fiães onde se encontrava parte da sua família. Participando, ativamente, na propaganda republicana que antecedeu a queda da Monarquia, foi eleito deputado, em 1911, pelo círculo de Estarreja e, em 1915, pelo de Penafiel, representando as listas do Partido Republicano Português ${ }^{69}$. No entanto, em 1913, José Bessa de Carvalho encontrava-se incapacitado - devido a problemas de saúde - de prosseguir com os seus trabalhos parlamentares ${ }^{70}$, embora tenha sido nomeado vogal do Conselho de Administração dos Caminhos de Ferro do Estado ${ }^{71}$.

Outro «rosto» do republicanismo em Espinho foi o de Manuel Laranjeira. Nascido em 1877, na freguesia de Mozelos, em Santa Maria da Feira, fixou residência em Espinho, em 1899. No mesmo ano, com 22 anos, ingressou na Escola Médico-Cirúrgica do Porto, concluindo o curso em 1907, com a tese intitulada $A$ Doença da Santidade ${ }^{72}$. Iria destacar-se como uma figura influente da cultura portuguesa, mas a sua participação na vida de Espinho não se ficou

\footnotetext{
${ }^{63}$ Em 1893, formou-se em Direito na Universidade de Coimbra.) MARQUES, A. H. de Oliveira (coord.) Parlamentares e Ministros da 1. ${ }^{a}$ República (1910-1926). Lisboa: Assembleia da República, 2000, p. 153.

${ }^{64}$ MARQUES, A. H. de Oliveira (coord.) - Parlamentares e Ministros da 1. ${ }^{a}$ República (1910-1926). Lisboa: Assembleia da República, 2000, p. 153.

65 "Meu caro Berrêdo". Gazeta de Espinho, n. ${ }^{\circ}$ 511, 06.11.1910, p. 1.

66 “Dr. José Bessa de Carvalho". Gazeta de Espinho, n. ${ }^{\circ}$ 511, 06.11.1910, p. 1.

${ }^{67}$ Idem, p. 2.

68 "Meu caro Berrêdo". Gazeta de Espinho, n. ${ }^{\circ}$ 511, 06.11.1910, p. 1.

${ }^{69}$ MARQUES, A. H. de Oliveira (coord.) - Parlamentares e Ministros da 1. ${ }^{a}$ República (1910-1926), p. $153-154$.

${ }^{70}$ AMORIM, Ana Patrícia Cordeiro de Sousa - Exposição - Rostos da República. No âmbito das comemorações do Centenário da República em Espinho, p. 86.

${ }^{71}$ MARQUES, A. H. de Oliveira (coord.) - Parlamentares e Ministros da 1. ${ }^{a}$ República (1910-1926), p. 154.

${ }^{72}$ AMORIM, Ana Patrícia Cordeiro de Sousa - Exposição - Rostos da República. No âmbito das comemorações do Centenário da República em Espinho, p. 96.
} 
pela colaboração intelectual. Ao longo da sua vida, escreveu na Gazeta de Espinho artigos de opinião e integrou, por várias vezes, a Comissão Municipal Republicana ${ }^{73}$. Como republicano, Manuel Laranjeira distinguia-se, essencialmente, como orador nos comícios democráticos ${ }^{74}$. Esteve sempre na linha de combate ao regime monárquico, apesar de ter cortado relações com Joaquim Pinto Coelho "por alegadas «discussões jornalísticas»"75.

O negociante Francisco de Resende foi primeiro secretário da Comissão Municipal Republicana. Aquando da instauração da República e da transição do poder municipal, foi eleito aferidor do concelho ${ }^{76}$ de Espinho $^{77}$.

Alfredo Berredo, professor de ensino livre, foi também membro da Comissão Municipal, sendo nomeado vereador da Comissão Administrativa, em $1910^{78}$. Outro membro republicano foi Manuel Casal Ribeiro e apresentava-se como presidente da Comissão Paroquial ${ }^{79}$. No seu estabelecimento comercial os republicanos inscreviam-se no cadastro partidário. Em 1911, pertenceu à Comissão Organizadora do Centro Democrático de Espinho e foi membro das Comissões políticas do Partido Republicano de Espinho ${ }^{80}$.

O mais influente dos republicanos de Espinho, neste período, foi Joaquim Pinto Coelho. Nascido no concelho de Santa Maria da Feira, a 27 de fevereiro de 1868, licenciou-se em Medicina pela Escola Médico-Cirúrgica do Porto. Três anos depois da conclusão do curso fixou-se em Espinho, abrindo um consultório com o Dr. Correia Marques, na rua do Norte ${ }^{81}$. Exerceu também a sua profissão na Associação de Socorros Mútuos ${ }^{82}$. Em 1901, ajudou a fundar a Gazeta de Espinho. Presidiu à segunda Câmara Municipal, integrando uma lista única que reunia membros do «Grupo da Fábrica» ${ }^{83}$. No entanto, findo esse mandato, cortou relações com a fação monárquica dirigida por Augusto Gomes, associando-se ao Partido Progressista ${ }^{84}$. A evolução política de Pinto Coelho viria a colocá-lo na oposição ao regime monárquico,

\footnotetext{
${ }^{73}$ GAIO, Carlos Morais - A Génese de Espinho. Histórias e Postais, p. 387.

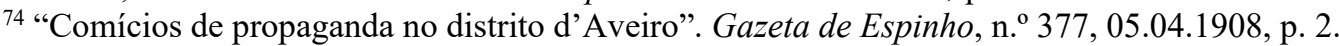

${ }^{75}$ GAIO, Carlos Morais - A Génese de Espinho. Histórias e Postais, p. 387.

${ }^{76} \mathrm{O}$ aferidor do concelho era um funcionário municipal encarregado de zelar pela verificação dos pesos e medidas usados no concelho, para a sua exatidão e evitar fraudes.

77 Arquivo Municipal de Espinho - Atas da Câmara Municipal de Espinho, 1910. Sessão de vereação de 10.10.1910.

${ }^{78}$ Arquivo Municipal de Espinho - Atas da Câmara Municipal de Espinho, 1910. Sessão de vereação de 20.10.1910.

79 “Partido Republicano". Gazeta de Espinho, n. ${ }^{\circ} 445,25.07 .1909$, p. 1.

${ }^{80}$ AMORIM, Ana Patrícia Cordeiro de Sousa - Exposição - Rostos da República. No âmbito das comemorações do Centenário da República em Espinho, p. 94.

81 “Anúncio". Gazeta de Espinho, n. ${ }^{\circ}$ 402, 27.09.1908, p. 3.

${ }^{82}$ GAIO, Carlos Morais - A Génese de Espinho. Histórias e Postais, p. 220.

${ }^{83}$ Repare-se que se trata de uma coligação monárquica promovida pelos industriais da fábrica de conservas Brandão Gomes.

${ }^{84}$ GAIO, Carlos Morais - A Génese de Espinho. Histórias e Postais, p. 221.
} 
aderindo ao Partido Republicano em $1905^{85}$. Em 1907, transformou a Gazeta em órgão oficial do Partido Republicano. Era o líder incontestado do PRP no concelho: presidia à Comissão Municipal Republicana e como candidato republicano às eleições municipais obtinha o maior número de votos entre os seus correligionários ${ }^{86}$. Joaquim Pinto Coelho assumia-se como o principal «rosto» da oposição ao «Grupo da Fábrica». Desde cedo levou a Gazeta de Espinho a tomar posição na disputa pelo poder, criticando a atuação da coligação monárquica, liderada por Henrique Brandão. O seu pensamento político e a sua conceção do mundo inspiraram-se na trilogia da Revolução Francesa, sofrendo influências da irrupção republicana de 1870 e, sobretudo, na Revolução de janeiro de $1891^{87}$.

Em Espinho, existiam várias opiniões políticas, mas destacavam-se núcleos de indivíduos bem relacionados, que pretendiam o progresso da sociedade. Nas eleições paroquiais de 1908, Joaquim Pinto Coelho promoveu a criação de uma lista, em que prevaleciam elementos republicanos, apoiados pelos grupos dissidentes e progressistas, para se oporem ao «Grupo da Fábrica», promovido pelos industriais da fábrica de conservas Brandão Gomes. Ao contrário dos republicanos, que se guiavam pela "fé, coragem, o patriotismo dos que combatem com uma causa nobre" ${ }^{88}$, esta coligação monárquica, composta por assalariados, não dispunha de um programa ou princípios. Numa dura crítica, o líder carismático do PRP, em Espinho, afirmava:

Essa união que não sabe de que freguesia é, congrega vários elementos dispersos de diferentes fações e outros anódinos. É uma firma [...] Forma o grosso desse exército um grupo de assalariados e mendicantes que combatem, a pé firme, de papo feito, como se tivessem a barriga cheia de... convicções. Coitados! ${ }^{89}$.

Os republicanos consideravam ser impossível compor, com dignidade, uma Câmara Municipal ou uma Junta Paroquial com indivíduos defensores da política dominante. Se era impraticável reunir nomes de indivíduos extrapartidários para gerir o concelho, tornar-se-ia possível agrupar elementos aliados em partidos, que pudessem impulsionar a administração por normas económicas. Deste modo, Joaquim Pinto Coelho pretendia a adesão de unidades harmoniosas para neutralizar a influência dos grupos partidários ${ }^{90}$.

Após a revolução de 5 de outubro de 1910, foi eleito representante do Governo Provisório da República em Espinho ${ }^{91}$. Em 1910, tomou posse do cargo de presidente da Câmara Municipal, cargo que manteve até agosto do ano seguinte, altura em que, por

\footnotetext{
${ }^{85}$ QUINTA, João - Espinho. Espinho, 1999, p. 221.

86 "Republicanos d'Espinho". Gazeta de Espinho, n. ${ }^{\circ} 408,08.11 .1908$, p. 1.

${ }^{87}$ LOPES, António Teixeira - O Nascimento de um Aglomerado Urbano: Espinho no Limiar do Século XX, p. 136.

88 "Republicanos d'Espinho". Gazeta de Espinho, n. ${ }^{\circ} 406,25.10 .1908$, p. 1.

89 "Eleições Paroquiais". Gazeta de Espinho, n. ${ }^{\circ} 412,06.12 .1908$, p. 1.

90 "Republicanos d'Espinho". Gazeta de Espinho, n. ${ }^{\circ} 406,25.10 .1908$, p. 1.

${ }^{11}$ Arquivo Municipal de Espinho - Atas da Câmara Municipal de Espinho, 1910. Sessão de vereação de 10.10.1910.
} 
incompatibilidade de funções, passaria a exercer apenas o cargo de administrador do concelho $^{92}$. Voltaria ainda a presidir à Câmara de Espinho, em 1913 e em 1916.

\subsection{A participação do Partido Republicano em Espinho nas eleições} municipais e paroquiais

\subsubsection{As eleições de 1908}

Desde a primeira reunião, em 1905, o Partido Republicano tinha vindo a evoluir significativamente em Espinho. As adesões ao cadastro partidário eram reveladoras, incluindo figuras ilustres da sociedade. Em novembro de 1908, realizaram-se as eleições municipais e paroquiais, na Igreja Matriz de Espinho. Prevaleciam as listas monárquicas nas urnas, mas atentemos, sobretudo, nos resultados obtidos pelos candidatos republicanos, que foram bastante expressivos do crescimento do republicanismo no concelho.

\subsubsection{A campanha eleitoral}

Antes das eleições, na assembleia geral dos republicanos de Espinho, foram discutidos e preparados os passos da próxima luta eleitoral, incluindo a atitude que o partido devia adotar. O presidente da Comissão Municipal Republicana expôs os trabalhos realizados pelas respetivas Comissões, apelando às decisões soberanas da assembleia. Para as eleições camarárias, a assembleia concordou, de forma unânime, que o Partido Republicano de Espinho devia concorrer com uma lista única e "independente", organizada pela Comissão Paroquial e aprovada, em sessão conjunta, pela Comissão Distrital e pelo Diretório ${ }^{93}$.

Em Espinho, existiam várias opiniões políticas, representadas por nacionalistas, franquistas, regeneradores, progressistas e republicanos, verificando-se a impossibilidade de congregar "as forças dispersas [...] que deem um conjunto de nove ou doze nomes capazes de agrupar numa lista homogénea, genuinamente extrapartidária"94. No período eleitoral, os republicanos utilizaram a Gazeta de Espinho para desenvolver a sua campanha eleitoral, apelando ao voto do povo espinhense nas urnas pelos "homens que advogam a liberdade"95. De maneira a promover o engrandecimento democrático, criticavam, duramente, a ação monárquica, alegando:

Diversos são os campos, extremados ficam os meios de combate. As armas dos monárquicos são ainda as seitas bárbaras que levam o veneno corruptor das consciências; a estratégia dos nossos adversários é o assalto e a pilhagem [...] os nossos soldados levam a fé [...] não

\footnotetext{
${ }^{92}$ AMORIM, Ana Patrícia Cordeiro de Sousa - Exposição - Rostos da República. No âmbito das comemorações do Centenário da República em Espinho, p. 97.

93 "Partido Republicano de Espinho". Gazeta de Espinho, n. ${ }^{\circ} 406,25.10 .1908$, p. 1.

94 “Republicanos de Espinho". Gazeta de Espinho, n. ${ }^{\circ} 406,25.10 .1908$, p. 1.

95 “Ao Povo d'Espinho”. Gazeta de Espinho, n. ' 377, 05.04.1908, p. 1.
} 
assaltam o poder à força de «bainetes» [...] o nosso partido advoga a causa da Pátria! A urna, pois! Pelo partido republicano! ${ }^{96}$

\subsubsection{Os principais candidatos às eleições municipais e paroquiais}

Com o objetivo de concorrer com uma lista «independente» nas eleições municipais, a Comissão Paroquial escolheu uma lista de cinco efetivos composta por Joaquim Pinto Coelho (médico), Manuel Fernandes Laranjeira (médico), Francisco Pereira de Resende (comerciante), Eurico C. Pouzada (industrial) e Alberto Delgado (farmacêutico). A lista dos cinco substitutos era constituída por Álvaro L. de Magalhães (proprietário), Joaquim A. Moreira Ramos (cirurgião-dentista), Carlos de Figueiredo (industrial), Alfredo Berredo (professor de ensino livre) e Alberto de Carvalho (fotógrafo) ${ }^{97}$. As duas Comissões - Municipal e Paroquial reuniram-se para a aprovação definitiva da lista apresentada.

Nas eleições paroquiais foi organizada uma lista, em que predominavam elementos republicanos, apoiada por dissidentes e progressistas. A Comissão Paroquial constituiu uma lista de seis efetivos, destacando-se Alberto Delgado, Manuel Casal Ribeiro, Armínio Alves Vieira, Manuel Alves Lima, Pompeu Duarte de Araújo e António Cruz. A lista dos substitutos foi composta por Manuel Rodrigues e António Ferreira Neto.

\subsubsection{O ato eleitoral}

A eleição para a Câmara Municipal de Espinho, juntamente com a da Câmara da Feira, ocorreu a 1 de novembro, num domingo, terminando na madrugada de segunda-feira. Decorreu sem surpresas, embora não se possa dizer que houvesse extrema legalidade ou ausência de incidentes ${ }^{98}$.

O juiz da comarca optou pelo processo das chamadas «esferas de quino». O sorteio da presidência eleitoral era composto por 8 bolas, lançadas nas urnas. No entanto, aconteceu uma tentativa de fraude: quando as bolas chegaram ao Tribunal - depois do ajudante do sorteio - o Sr. Amorim - ter andado "de porta a porta, a correr [...] até que conseguiu arranjar as bolas em casa do negociante José Marques"99 - o escrivão pediu auxílio ao assistente para que lhe fornecesse as bolas de 1 a 16. Coexistiam dois jogos de bolas: um para o sorteio da Câmara da Feira e outro para a Câmara de Espinho, sem o expediente da extração. De acordo com a informação contida no órgão oficial republicano "procedeu-se sem incidentes ao sorteio das presidências da Feira, e por fim [...] quando o escrivão lançava as bolas na urna para o sorteio

\footnotetext{
96 “Republicanos de Espinho". Gazeta de Espinho, n. ${ }^{\circ} 406,25.10 .1908$, p. 1.

${ }^{97}$ Idem.

98 Através da Gazeta de Espinho, os republicanos enunciam que os relatores não deram importância às irregularidades ocorridas, centrando-se, essencialmente, na boa vontade e espírito conciliador do Presidente. "Ainda o sorteio da presidência eleitoral d'Espinho". Gazeta de Espinho, n. ${ }^{\circ}$ 408, 08.11.1908, p. 2.

99 “Ainda o sorteio da presidência eleitoral d'Espinho". Gazeta de Espinho, n. o 408, 08.11.1908, p. 2.
} 
de Espinho é que foram elas!"100. Uma das bolas era distinta das outras por uma falha - a bola n. ${ }^{0} 5$ - correspondente ao presidente da Câmara de Espinho em funções, Henrique Brandão, "o qual é [...] amigo pessoal do escrivão que interveio no sorteio" ${ }^{101}$. A intervenção dos cidadãos Ribeiro Nunes e Salvador Júnior foram imediatas para compreender o motivo da falha. Aquando da insistência dos dois cidadãos, o escrivão - após anunciar "«aquilo nada valia e era caruncho»"102 - compreendeu que se levantava uma suspeita. Rapidamente, a bola foi excluída pelo juiz da comarca, que reconheceu o papel do cidadão pela falha apurada ${ }^{103}$.

Nas eleições paroquiais, realizadas a 29 de novembro, na Igreja Matriz de Espinho, o ato eleitoral decorreu em dois dias, apesar de não haver incidentes. Contudo, os republicanos criticaram a forma usada pela coligação monárquica da fábrica Brandão Gomes, para obter o maior número possível de votos. No dia das eleições, os operários da Brandão Gomes, juntamente com os dirigentes do «Grupo da Fábrica», "passaram uma noite atribulada. E no dia seguinte lá vinham a caminho da Igreja todos os recrutados - doentes e aleijados. Tudo a postos!"104.

\subsubsection{Os resultados do Partido Republicano}

De uma maneira geral, nas eleições municipais, os nomes presentes na lista eleitoral do PRP obtiveram um número significativo de votos. Observando a tabela abaixo é possível percecionar o número de votos obtido pelos candidatos efetivos e suplentes das listas monárquicas e republicanas:

Tabela 1: Os resultados das eleições municipais de 1908 (n. ${ }^{\circ}$ de votos em cada candidato)

\begin{tabular}{|c|c|c|c|c|c|c|}
\hline Efetivos: & L & V & & Suplentes: & L & V \\
\hline $\begin{array}{c}\text { José António Pires de } \\
\text { Resende }\end{array}$ & M & 208 & & Lourenço Luís de Pinho & M & 207 \\
\hline $\begin{array}{c}\text { António Augusto de } \\
\text { Castro Soares }\end{array}$ & $\mathrm{M}$ & 207 & & $\begin{array}{c}\text { Manuel Alves da Silva } \\
\text { Capitão }\end{array}$ & M & 205 \\
\hline $\begin{array}{c}\text { Alberto Jorge Moreira } \\
\text { Pinto }\end{array}$ & $\mathrm{M}$ & 207 & & Alberto de Carvalho & M & 205 \\
\hline $\begin{array}{c}\text { Narciso André de Lima } \\
\text { Eurico Carlotti Pousada }\end{array}$ & $\mathrm{M}$ & 207 & & Alberto Milheiro & $\mathrm{M}$ & 204 \\
\hline Joaquim Pinto Coelho & $\mathrm{R}$ & 175 & & João Francisco da Silva & M & 154 \\
\hline
\end{tabular}

\footnotetext{
${ }^{100}$ Idem.

${ }^{101}$ Idem.

102 Idem.

103 Idem.

104 “Eleições Paroquiais". Gazeta de Espinho, n. ${ }^{\circ}$ 412, 06.12.1908, p. 1.
} 


\begin{tabular}{|c|c|c|c|c|c|}
\hline $\begin{array}{c}\text { António Montenegro } \\
\text { dos Santos }\end{array}$ & $\mathrm{M}^{*}$ & 169 & $\begin{array}{c}\text { P.e António Rodrigues } \\
\text { Moreira Garção }\end{array}$ & M & 154 \\
\hline Manuel Ribeiro Nunes & M & 167 & $\begin{array}{c}\text { Francisco Pinto Moreira } \\
\text { Ramos }\end{array}$ & M & 153 \\
\hline $\begin{array}{l}\text { António de Oliveira } \\
\text { Salvador Júnior }\end{array}$ & M & 165 & $\begin{array}{l}\text { Francisco Joaquim } \\
\text { Pereira de Resende* }\end{array}$ & $\mathrm{R}$ & 153 \\
\hline $\begin{array}{l}\text { Manuel Luís de Oliveira } \\
\text { Costa }\end{array}$ & M & 163 & $\begin{array}{c}\text { Joaquim de Sá Alves de } \\
\text { Oliveira }\end{array}$ & M & 152 \\
\hline $\begin{array}{l}\text { Francisco Joaquim } \\
\text { Pereira de Resende }\end{array}$ & $\mathrm{R}$ & 19 & $\begin{array}{c}\text { Carlos Alves de } \\
\text { Figueiredo }\end{array}$ & $\mathrm{R}$ & 20 \\
\hline Alberto Delgado & $\mathrm{R}$ & 7 & Manuel Casal Ribeiro & $\mathrm{R}$ & 20 \\
\hline $\begin{array}{c}\text { Alfredo J. Pereira de } \\
\text { Brito L. Barredo }\end{array}$ & $\mathrm{R}$ & 7 & $\begin{array}{c}\text { Manuel Gomes } \\
\text { Ferreirinha Novo }\end{array}$ & $\mathrm{R}$ & 20 \\
\hline \multirow[t]{5}{*}{$\begin{array}{l}\text { Joaquim Augusto } \\
\text { Moreira Ramos }\end{array}$} & $\mathrm{R}$ & 6 & $\begin{array}{c}\text { Álvaro Lambertini de } \\
\text { Magalhães }\end{array}$ & $\mathrm{R}$ & 19 \\
\hline & & & Manuel Alves Lima & $\mathrm{R}$ & 19 \\
\hline & & & António Marques & $\mathrm{M}$ & 1 \\
\hline & & & $\begin{array}{c}\text { Joaquim Pedro } \\
\text { Rodrigues }\end{array}$ & M & 1 \\
\hline & & & $\begin{array}{l}\text { Manuel António dos } \\
\text { Santos }\end{array}$ & M & 1 \\
\hline $\begin{array}{l}\text { * Incluído em lista } \\
\text { monárquica }\end{array}$ & & & $\begin{array}{c}\text { José Alves Pereira da } \\
\text { Silva }\end{array}$ & M & 1 \\
\hline
\end{tabular}

FONTE: “Eleição da Câmara de Espinho”. Gazeta de Espinho, n. o 408, 08.11.1908, p. 1.

Da análise da tabela 1, percebe-se que o republicano efetivo mais votado foi Joaquim Pinto Coelho, com 175 votos e o menos votado Joaquim Ramos, com 6 votos. Apesar do peso do número de votos obtidos pelos nomes da lista oficial do PRP, em 1908, as listas monárquicas continuavam a controlar as eleições. O monárquico mais votado conquistou 208 votos.

Sem embargo, importa ressaltar que, aquando das eleições, um grupo monárquico apresentou uma lista com dois nomes pertencentes à lista oficial do PRP, entre os quais Eurico Carlotti Pouzada ${ }^{105}$, na lista efetiva e Francisco Joaquim Pereira de Resende ${ }^{106}$, na lista suplente. Continha, também, entre os efetivos, o nome de António Montenegro dos Santos, dissidente.

\footnotetext{
${ }^{105}$ Foi anunciado pelo órgão oficial republicano - Gazeta de Espinho -, como um dos cinco candidatos efetivos da lista definitiva do PRP para a eleição da Câmara Municipal de Espinho.

${ }^{106}$ Do mesmo modo, foi anunciado como um dos cinco candidatos efetivos republicanos às eleições municipais de 1908. No resultado geral da votação de vereadores efetivos, Francisco Joaquim de Resende anuncia-se como candidato republicano - com 19 votos - e na votação de vereadores substitutos é incluído na lista monárquica com 153 votos.
} 
De acordo com a Gazeta de Espinho, os republicanos incluídos na lista monárquica declararam "dizendo que não haviam autorizado nem solicitado tal deferência""107.

Foram eleitos os cinco mais votados dos efetivos: José António Rezende, monárquico; António Augusto Castro Soares, monárquico; Alberto Jorge Moreira Pinto, monárquico; Narciso André de Lima, monárquico; e Eurico C. Pouzada, monárquico ${ }^{108}$. Não obstante, os cinco substitutos eleitos para a Câmara de Espinho conquistaram correspondiam às listas monárquicas $^{109}$.

No que concerne às eleições paroquiais, podemos analisar os números de votos em cada candidato da oposição à lista monárquica União, pertencente ao «Grupo da Fábrica»:

Tabela 2: Os resultados das eleições paroquiais de 1908 (n. ${ }^{\circ}$ de votos em cada candidato da oposição)

\begin{tabular}{|c|c|c|c|c|c|}
\hline Efetivos: & $\mathbf{L}$ & $\mathbf{V}$ & Suplentes: & $\mathbf{L}$ & $\mathbf{V}$ \\
\hline Alberto Delgado & $\mathrm{R}$ & 128 & Manuel Luís Rodrigues & $\mathrm{R}$ & 128 \\
\hline Manuel Casal Ribeiro & $\mathrm{R}$ & 128 & António Ferreira Neto & $\mathrm{R}$ & 126 \\
\hline Domingos Fernandes de Oliveira & $\mathrm{D}$ & 127 & Francisco Ferreira Pedro & $\mathrm{P}$ & 127 \\
\hline Armínio Alves Vieira & $\mathrm{R}$ & 125 & João Valente Arruda & $\mathrm{D}$ & 123 \\
\hline Manuel Alves Lima & $\mathrm{R}$ & 1 & Pompeu Duarte Araújo & $\mathrm{R}$ & 4 \\
\hline António Cruz & $\mathrm{R}$ & 1 & & & \\
\hline $\begin{array}{l}\text { O mais votado da lista monárquica União } \\
\text { obteve } 188 \text { votos e o menos votado } 136 \text { votos. }\end{array}$ & & & & & \\
\hline
\end{tabular}

FONTE: Eleições Paroquiais". Gazeta de Espinho, n. ${ }^{\circ}$ 412, 06.12.1908, p. 1.

Conforme é percetível na tabela 2 , os candidatos da oposição mais votados correspondiam às listas republicana e dissidente, com 128 votos alcançados pelos republicanos Alberto Delgado e Manuel Casal Ribeiro e pelo dissidente Domingos Fernandes de Oliveira. Efetivamente, os republicanos menos votados foram Manuel Alves Lima, Pompeu Duarte de Araújo e António Cruz, com 1 voto. O mais votado da lista monárquica União foi o sr. Abade, com 188 votos, e o menos votado dos efetivos obteve 136 votos. Na lista suplente, o republicano mais votado conquistou 128 votos, salientando-se, o número de votos alcançados pelos candidatos progressista - Francisco Ferreira Pedro (com 127 votos) - e dissidente - João Valente Arruda (com 123 votos) ${ }^{110}$.

\footnotetext{
107 “Eleição da Câmara de Espinho”. Gazeta de Espinho, n. ' 408, 08.11.1908, p. 1.

108 Idem.

${ }^{109}$ Idem.

110 "Eleições Paroquiais". Gazeta de Espinho, n. ${ }^{\circ}$ 412, 06.12.1908, p. 1.
} 


\subsubsection{A reação do Partido Republicano às eleições municipais e paroquiais de 1908}

Embora obtivessem votos consideráveis nas eleições municipais, os republicanos criticaram a forma como se tinha realizado o ato eleitoral. Tendo em conta a tentativa fraudulenta, ocorrida no sorteio da presidência eleitoral de Espinho, os republicanos censuraram o processo de bolas utilizado:

Estranhamos, sim, como era natural, que se recorresse a um processo de bolas e que, pelo visto, deu tanto trabalho, quando tão simples [...] fora lançar numa urna um número de lista igual ao dos vereadores sorteados, distribuindo por eles os respetivos nomes, e a primeira que se extraísse indicaria o presidente da assembleia eleitoral de que tratava, por só uma constituir o concelho de Espinho. ${ }^{111}$

Não obstante, criticaram o escrivão nomeado por não ter dado conta da abertura a canivete na bola de madeira, argumentando "se bem que desde Aristóteles até aos nossos dias não consta que zoologista algum haja descoberto semelhante habilidade quando ele mine comprometedoramente bolas de quino? Ou seria apenas falha no nó da madeira? ${ }^{12}$ ", solicitando um inquérito para averiguar a verdade, não formulando suspeitas sobre quem seriam os responsáveis.

Aquando da tomada de posse da nova Câmara de Espinho, a vereação decidiu enviar um voto de condolências ao rei D. Manuel II, pelo assassinato de seu pai e seu irmão. A mensagem municipal atentava que "estas ondas avassaladoras de amor e simpatia pela monarquia portuguesa [...] são testemunho frisante das altas qualidades que ornam V.M." ${ }^{113}$, incluindo, ainda, outro recado da Comissão de Melhoramentos. Neste sentido, os republicanos criticaram o novo poder municipal:

Por felicidade S.M. não ouviu as razões de muitas outras comissões. Espinho é a terra das comissões. Parecem pragas do Egito. Ora, se cada comissão vinha com o seu discurso, ainda a estas horas a monarquia não teria almoçado! [...] Em compensação - nesta vida tudo tem compensações - nos baixos do edifício, por distração, entrou à noite um guarda da polícia, fardado. O tipo era lisboeta, quis certificar-se do que seria um casino em Espinho e ficou deslumbrado ao ver tantos reis pintados! Oh! O faro da polícia ${ }^{114}$.

Nas eleições paroquiais, face à vitória do «Grupo da Fábrica», os republicanos criticaram o exército de assalariados e mendicantes, obrigados a votarem na coligação monárquica, argumentando, "pois mal sentiram o rebate de luta, puseram-se em campo os cabos de ordens e toca a reunir [...] Não foi má a partida para os invencíveis" ${ }^{115}$.

\footnotetext{
111 “Ainda o sorteio da presidência eleitoral d'Espinho". Gazeta de Espinho, n. ${ }^{\circ}$ 408, 08.11.1908, p. 2.

${ }_{112}$ Idem.

113 "Episódios da régia receção em Espinho". Gazeta de Espinho, n. ${ }^{\circ}$ 411, 29.11.1908, p. 1.

${ }^{114}$ Idem

${ }^{115}$ Idem.
} 


\section{A implantação da República em Espinho}

\subsection{A proclamação da República em Espinho}

O regime monárquico encontrava-se em profunda crise. Para os republicanos «a República era [...] a salvação da pátria, o ideal, a possibilidade de atingir um estádio de maior perfeição» ${ }^{116}$. Efetivamente, exigiam um Estado democrático, com o poder executivo submetido a um Parlamento, um chefe com poder restringido e o aumento da participação popular ${ }^{117}$.

$\mathrm{Na}$ manhã de 5 de outubro, as tropas oficiais tinham-se rendido, considerando-se incapazes de fazerem frente aos revoltosos. Nas terras mais importantes do País foi proclamada a República - "No Porto, em Braga, em Coimbra, em Viana do Castelo e em todas as povoações do sul do país o advento da República foi celebrado com verdadeiro delírio"118. Em Espinho, pela meia-noite de quarta para quinta-feira (5 para 6 de outubro), chegaram por comboio os primeiros relatos da queda da Monarquia. Todavia, só no dia 6 , às $7 \mathrm{~h}$, foi confirmada a vitória dos republicanos. Reuniram na Escola António José de Almeida todos os vogais das Comissões Republicanas, Concelhia e Paroquial e, assim que chegou a notificação, resolveram promover demonstrações festivas ${ }^{119}$. Inicialmente, tratava-se de notícias vagas e indefinidas, que só mais tarde seriam confirmadas pelo Diário do Governo, entregue ao presidente da Comissão Municipal Republicana, Pinto Coelho. Pouco tempo depois, na varanda do Paços do Concelho, foi proclamada a República, hasteando-se a bandeira bicolor ${ }^{120}$ :

Foi, em seguida, proclamada a República, da varanda do Paços do Concelho onde se hasteou a bandeira do partido que desde então ali tremula beijada pelo mesmo sol, coberta pelo mesmo céu e bafejada pela mesma aragem que, neste canto formoso do país, nesta risonha praia do Norte, beijou, cobriu e bafejou o pendão monárquico ${ }^{121}$.

No sábado, 8 de outubro, Joaquim Pinto Coelho partiu para Aveiro, na dupla qualidade de presidente da Comissão Municipal Republicana e chefe do Partido Republicano de Espinho. Às 22h, regressou a Espinho com o alvará de administrador do concelho, entregue pelo Governador Civil, Albano Coutinho. A posse do republicano e cidadão Pinto Coelho realizouse, em seguida, "sendo um dos atos mais concorridos que neste concelho se tem efetuado"122. À cerimónia assistiram pessoas de todas as condições sociais, quer por disciplina partidária, quer amigos dedicados do novo funcionário do Estado, contando com a presença de médicos,

\footnotetext{
${ }^{116}$ ROSAS, Fernando; ROLLO, Maria Fernanda (coord.) - História da Primeira República portuguesa, p. 71.

${ }^{117}$ GAIO, Carlos Morais - A Génese de Espinho. Histórias e Postais, p. 232.

118 “A proclamação da República”. Gazeta de Espinho, n. ${ }^{\circ}$ n. ${ }^{\circ}$ 508, 09.10.1910, p. 1.

${ }^{119}$ BRANDÃO, Francisco Azevedo - Anais da História de Espinho (985-1926). Espinho: CME/JFE, 1991, p. 169.

120 “A proclamação da República - Em Espinho”. Gazeta de Espinho, n. ${ }^{\circ}$ 508, 09.10.1910, p. 1-2.

121 "Casos e Notícias". Gazeta de Espinho, n. ${ }^{\circ}$ 508, 09.10.1910, p. 2.

122 “A proclamação da República - Em Espinho”. Gazeta de Espinho, n. ${ }^{\circ}$ 508, 09.10.1910, p. 1-2.
} 
advogados, militares e capitalistas. As repartições municipais que se encontravam no mesmo edifício foram seladas, dando-se conhecimento oficial à imprensa de Lisboa e do Porto, por telegrama, do ato que se tinha realizado. Terminada a assinatura do auto, Joaquim Pinto Coelho proferiu um vibrante discurso, enaltecendo a República, jurando servi-la com dedicação e defendê-la com coragem e valor, pela sua honra ${ }^{123}$.

\subsection{A reação do povo à mudança de regime}

Os populares começaram a festejar a queda do regime monárquico. Apesar de serem tomadas rigorosas precauções para garantir a ordem, foi organizado um cortejo em direção à casa da Câmara, onde estavam presentes os representantes oficiais do Partido Republicano de Espinho. Na Escola António José de Almeida realizou-se uma sessão solene, iniciando-se as manifestações nas ruas. À noite, ao som do hino «A Portuguesa», tocada pela banda de música da Brandão Gomes ${ }^{124}$, o povo percorreu as ruas, num numeroso cortejo com archotes. Nos casinos Peninsular e Chinês, os republicanos exigiam que o hino fosse ouvido de pé e com respeito como "uma religião - a pátria - e o entusiasmo na alma"125. No quartel da Guarda Fiscal foi erguida a bandeira republicana, numa confraternização comovente entre os republicanos civis e miliares ${ }^{126}$. No dia 7 de outubro, manteve-se o mesmo, se não um maior entusiasmo do que no dia anterior: perdurou a música nas ruas e nos casinos e repetiram-se as celebrações, iluminando as fachadas das habitações de vultos republicanos.

As festividades republicanas "não [eram] festa de cerimónia e protocolo como as que a monarquia fez aos seus reis, mas festa sincera, regozijo da alma popular, sem que para isso houvesse um incitamento, uma simples insinuação"127.

\subsection{A transição do poder municipal e a primeira Câmara Republicana}

A quarta vereação municipal iniciou o seu mandato a 23 de novembro de 1908 e deveria terminar a 31 de dezembro de 1910. Sem embargo, foi interrompido no contexto da Revolução de 5 de outubro de 1910, que pôs fim ao regime monárquico e deu origem à República.

Os vereadores efetivos que constituíam a Comissão Municipal de Espinho levantaram um viva à proclamação da República. Na sessão ordinária de 7 de outubro, começaram por referir que o povo português levou a cabo a implantação da República, através de uma revolução

\footnotetext{
123 “Casos e Notícias”. Gazeta de Espinho, n. ${ }^{\circ}$ 508, 09.10.1910, p. 2.

${ }^{124}$ GAIO, Carlos Morais - A Génese de Espinho. Histórias e Postais, p. 232.

125 “Casos e Notícias”. Gazeta de Espinho, n. ${ }^{\circ}$ 508, 09.10.1910, p. 2.

126 “A proclamação da República - Em Espinho”. Gazeta de Espinho, n. ${ }^{\circ}$ 508, 09.10.1910, p. 1-2.

127 “Casos e Notícias”. Gazeta de Espinho, n. ${ }^{\circ}$ 508, 09.10.1910, p. 2.
} 
extraordinária que impôs o respeito do mundo, integrando Portugal na mais alta civilização ${ }^{128}$. Graças a este acontecimento, a bandeira foi hasteada no edifício camarário, simbolizando a transformação das instituições monárquicas no regime republicano, compatível com todas as liberdades e as manifestações de dignidade humana "que devem dar força e igualdade [...] a uma era de luz e de progresso" $" 129$.

Outrossim, de maneira a testemunhar os seus sentimentos e interpretando os dos cidadãos de Espinho deliberaram enviar um telegrama ao presidente do Governo Provisório. Após tratarem do expediente essencial para a boa regularidade dos assuntos municipais, encerrou-se a sessão com um voto de regozijo pelo advento da República. O presidente da Câmara Municipal foi autorizado a assinar a ordem de proclamação.

A mudança de poder traduziu-se na ocupação dos lugares pelos republicanos mais conhecidos. No dia 10 de outubro, a Comissão Municipal Republicana tomou posse na Casa da Câmara. Foi investida em funções por Joaquim Pinto Coelho, representante do Governo Provisório da República, comissionado pelo Governador Civil de Aveiro, e por Alfredo Berredo, no cargo de vice-presidente. A Comissão Municipal Republicana foi constituída por Joaquim Pinto Coelho (médico); Alfredo Berredo (professor de ensino livre); Francisco Joaquim de Resende (negociante), com o cargo de aferidor do concelho; António Martins Cruz (fotógrafo); e Francisco Alves Vieira (negociante) ${ }^{130}$. No dia 11 de outubro, foi dada a posse pelo administrador do concelho à Comissão Paroquial que era constituída por Manuel Casal Ribeiro, Manuel Ferreirinha Novo, Joaquim Luís Rodrigues, António Pinto Loureiro, Pompeu Duarte Araújo, Domingos da Silva, Hilário Casal Ribeiro, Joaquim de Sousa Reis, António Ferreira Neto e Domingos de Oliveira ${ }^{131}$.

\subsection{As primeiras preocupações e medidas políticas tomadas pela primeira}

\section{Câmara Republicana}

Na sessão da tomada de posse, a primeira preocupação do presidente da Câmara foi declarar fidelidade à República. Declarou não fazer programas, argumentando que se havia de nortear pela moralidade em todos os atos de administração, tendo sido deliberado proceder a um inventário e inquérito aos serviços. Após a distribuição dos cargos da vereação, a Comissão Administrativa Municipal resolveu que as sessões passariam a realizar-se às quintas-feiras,

\footnotetext{
${ }^{128}$ Arquivo Municipal de Espinho - Atas da Câmara Municipal de Espinho, 1910. Sessão de vereação de 07.10.1910, p. 2.

${ }^{129}$ Idem, p. 3.

${ }^{130}$ Arquivo Municipal de Espinho - Atas da Câmara Municipal de Espinho, 1910. Sessão de vereação de 10.10.1910, p. $1-2$.

${ }^{131}$ BRANDÃO, Francisco Azevedo - Anais da História de Espinho (985-1926), p. 170.
} 
pelas $14 \mathrm{~h}^{132}$. Rapidamente, demonstraram estar com pressa de resolver os problemas que afetavam Espinho e, como tal, foi aprovado um conjunto de medidas ${ }^{133}$.

A 13 de outubro, o presidente propôs várias reformas, como a vistoria ao mercado pelo subdelegado de saúde e a necessidade de se realizar diversas obras públicas. Para além disso, aprovou que fosse transferido para o Banco de Portugal o dinheiro arrecadado no cofre da Câmara e o levantamento de 800 mil réis da Caixa Geral de Depósitos para o fundo da viação municipal. Outro tipo de questões - diretamente associadas à população - atentava a Câmara, como o problema de segurança e saúde pública - através da criação de uma rede de esgotos. Por iniciativa de Alfredo Berredo, propôs-se a criação de um corpo de polícia cívica ou a necessidade de combater o analfabetismo, através da fundação de um curso noturno para adultos ${ }^{134}$.

A Câmara Republicana tinha ainda outras preocupações sociais, relacionadas com as condições de trabalho e as necessidades das populações mais carenciadas. Entre outras medidas, logo em outubro de 1910, foi proposto que entrasse em vigor o horário de 8 horas de trabalho diário para os operários das conservas de Espinho ${ }^{135}$.

\subsection{O papel da Gazeta de Espinho na propaganda republicana}

\subsubsection{As principais críticas feitas aos poderes monárquicos}

Através da Gazeta de Espinho, os republicanos optavam por discutir e elucidar a população sobre o regime monárquico. Consideravam a Monarquia como "um regime [...] cheio de ficções e despotismos [...] com engrenagens carcomidas da ferrugem burocrática, compostos de calunias parasitarias de afilhadagem e compadrio" ${ }^{" 136}$.

Era cada vez mais visível que a ditadura de João Franco não servia os interesses nacionais, uma vez que procurava "vencer tudo pela força e pelo terror, ferindo os golpes da Liberdade e a Lei"137. Após a constituição do novo Governo - depois do episódio do regicídio - em 1908, os republicanos questionavam-se se os ministros monárquicos tinham capacidade de cumprir o programa, defendendo que não se deveriam sentar nas cadeiras do poder, se houvesse dignidade política em Portugal. Exemplo disso foi o chefe do Partido Progressista, Ferreira do Amaral. De maneira a sufocar a revolta dos marinheiros prometeu-lhes "sob palavra

\footnotetext{
${ }^{132}$ Arquivo Municipal de Espinho - Atas da Câmara Municipal de Espinho, 1910. Sessão de vereação de 10.10.1910, p. 1-2.

${ }^{133}$ LOPES, António Teixeira - O Nascimento de um Aglomerado Urbano: Espinho no Limiar do Século XX, p. 130.

134 Arquivo Municipal de Espinho - Atas da Câmara Municipal de Espinho, 1910. Sessão de vereação de 13.10.1910, p. 2-7.

135 Arquivo Municipal de Espinho - Atas da Câmara Municipal de Espinho, 1910. Sessão de vereação de 20.10.1910, p. 4.

136 "Revolução e ditadura". Gazeta de Espinho, n. ${ }^{\circ} 366,19.01 .1908$, p. 1.

137 “Desabafando...". Gazeta de Espinho, n. ${ }^{\circ} 369,09.02 .1908$, p. 1.
} 
de honra que se submetessem, que nada sofriam. Entretanto esses desgraçados, barbaramente condenados, expiam um castigo humilhante e desumano longe da pátria, em prisões que são--um túmulo para os vivos!"138.

Os republicanos criticavam todos aqueles que difamavam a República, considerando-os "nojentos os falsos apóstolos! Raça farisaica que tem vivido da mentira [...] o povo começa a conhecê-los" ${ }^{139}$. Tornava-se indispensável o surgimento de um movimento, entre os portugueses, para terminarem com o regime de mentiras ${ }^{140}$.

Em Espinho, o administrador do concelho também era visto como uma autoridade ditatorial e incompetente para resolver os problemas do concelho, devido à sua constante ausência. A título de exemplo destaca-se, em 1908, um episódio da falta de comparência do mesmo: Um membro da Comissão Municipal Republicana - Alberto Delgado - requereu uma licença para a realização de duas conferencias de propaganda eleitoral a serem realizadas no salão do Teatro Aliança. De facto, o administrador do concelho "atendeu ao requerido, dizendo ao apresentante e signatário do requerimento que lhe dava deferimento verbal e que se ele se responsabilizava pela manutenção da ordem, nem ia nem se faria representar nesse comício"141. Todavia, finda a primeira conferência a desordem havia-se instalado no Teatro, suscitando uma crítica por parte dos republicanos: "cumpra V. Ex. a o seu dever" ${ }^{142}$. Outro exemplo se poderia relacionar com a substituição do lugar de administrador perante a ausência administrador do efetivo. Um episódio caricato demonstra-nos a falta de responsabilidade no desempenho das funções administrativas:

Está ausente, em uso de licença, o sr. administrador efetivo. A falta de substituto passou o cargo ao Presidente da Camara. Este, tendo de retirar-se de Espinho por alguns dias, deixou investido no lugar, como é de lei, o vice-presidente da camara. Agora consta-nos que este último por estar doente, passa funções de administrador a outro colega. Neste andar temos administrador por concurso dentro em breve ${ }^{143}$.

Outrossim, na sequência da prisão de um industrial de Espinho - sendo ignorados os nomes, profissões e moradas dos captores - os republicanos revoltaram-se contra a sua detenção, argumentando: "Então prende-se e põe-se incomunicável um cidadão honrado e trabalhador por ter, no uso pleno de um direito conferido pelas leis do país, reclamado contra uma arbitrariedade!"144. O administrador do concelho, residente na Foz do Douro e ausente de Espinho, foi acusado de ser um ditador. Consequentemente, com a saída do administrador efetivo para o Porto, não delegando as suas funções a outrem, o Governador Civil não pôde

\footnotetext{
138 “Constituição do novo governo. O seu programa”. Gazeta de Espinho, n. ${ }^{\circ}$ 369, 09.02.1908, p. 1.

139 “A Nossa Propaganda”: Gazeta de Espinho, n. ${ }^{\circ} 377,05.04 .1908$, p. 1.

140 "Eleitores, A 'urna pelos candidatos republicanos". Gazeta de Espinho, n. ${ }^{\circ}$ 502, 28.08.1910, p. 2.

141 “A política monárquica de Espinho”. Gazeta de Espinho, n. ${ }^{\circ}$ 377, 05.04.1908, p. 2.

142 Idem.

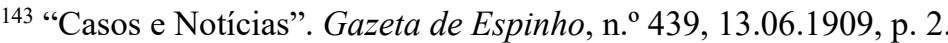

144 “Ditadura Local”. Gazeta de Espinho, n. ${ }^{\circ}$ 432, 25.04.1909, p. 2.
} 
suspender o administrador, o qual tinha todas as garantias de independência no exercício do seu cargo. Rapidamente, os republicanos apresentaram a sua opinião, argumentando:

Não nos prendem considerações pessoais, nem nos demovem ódios ou ressentimentos. Fiquem-no sabendo todos os apaniguados ou adeptos de qualquer parcialidade monárquica. No caso do sujeito, por curiosidade de crónica, no uso livre de crítica - tiramos este conceito moral do conto, pelo lado político - ficou deploravelmente colocada a política do sr. Governador Civil neste concelho. Assim seja para maior lastro das instituições que felizmente nos regem.... bien ... le dernier ${ }^{145}$.

\subsubsection{A notícia do Regicídio}

Em fevereiro de 1908, D. Carlos e o príncipe herdeiro foram assassinados. Os republicanos consideravam que a obra da ditadura franquista foi a grande causa da tragédia ocorrida: "a impressão atual que resulta do consenso quase unânime de opinião: a obra desvairada, incongruente e retrógrada de um governo antiliberal armou aquela tragédia"146.

De acordo com os republicanos, a política nociva de João Franco teve o seu fim a 1 de fevereiro de 1908. As vítimas e os mártires do ditador apenas defendiam um ideal de justiça e liberdade. O martírio era "um sentimento altruísta [...] uma abnegação sublime!"147. A propaganda republicana estava feita e a agitação popular começou-se a impor. O povo português, cansado da perseguição ditatorial, compreendeu os seus direitos e deveres, começando a desejar um governo do povo pelo povo, servido por homens da sua confiança ${ }^{148}$.

\subsubsection{As principais vantagens destacadas pela Gazeta na defesa do regime} republicano em contraste com o regime monárquico

Os republicanos criticavam, vivamente, a Monarquia, como um regime corrupto, ditatorial e de hábitos anacronicamente errados. Consideravam que a política "criminosa" adotada pelo regime monárquico tinha provocado a ruína económica e os partidos tradicionais "já não têm mais a arte de iludir" "149. A Monarquia era caraterizada por um regime "de mentiras, de crimes e de trapaças, do regime vilipendioso, da lama e das delapidações"150. Os monárquicos eram "seitas bárbaras"151, que conquistavam os postos avançados a preço de dinheiro e pela força. Tornava-se cada vez mais evidente que o povo se cansava da perseguição ditatorial, mas a República era ainda considerada como causadora da desordem e da anarquia: "a ideia da República atormentava a inteligência do rude aldeão, [...] era ela a morte e a violação da

\footnotetext{
145 “Política Local”. Gazeta de Espinho, n. ${ }^{\circ} 433,02.05 .1909$, p. 2.

146 “O fim trágico de uma ditadura mesquinha - período tenebroso de opressões, de ódios e vinganças". Gazeta de Espinho, n. ${ }^{\circ}$ 369, 09.02.1908, p. 1.

${ }^{147}$ Idem.

148 “Desabafando...". Gazeta de Espinho, n. ${ }^{\circ} 369,09.02 .1908$, p. 1.

149 “A Nossa Propaganda”. Gazeta de Espinho, n. 377, 05.04.1908, p. 1.

150 “Eleitores, à urna pelos candidatos republicanos”. Gazeta de Espinho, n. ${ }^{\circ}$ 502, 28.08.1910, p. 2.

151 “Republicanos d'Espinho". Gazeta de Espinho, n. ${ }^{\circ}$ 406, 25.10.1908, p. 1.
} 
propriedade" ${ }^{152}$. Além disso, os republicanos criticavam as festas monárquicas, considerando que não passavam de cerimónias e protocolos ${ }^{153}$.

Ainda assim, aquando do episódio do regicídio, a difusão republicana atingia o seu auge, "agitando a alma popular, não antecipa os acontecimentos [...] impõe-se, cala no animo da nação ultrajada, perseguida por tantos desastres e sequiosa de ter o governo do povo pelo povo, servido por homens [...] que rompam, de vez, com os privilégios e com as tradições" 154 .

A República era pregada “pelos seus apóstolos devotados"155 e "continua a ser a única esperança do nosso sentir patriótico" ${ }^{156}$. Os republicanos guiavam-se pela fé, coragem e patriotismo "dos que combatem com uma causa nobre. [...] Não vamos para a batalha terrível, em que as consciências e vendem à custa de um regabofe de bacanal; tendemos a assegurar bem alto o pendão da liberdade e o farol da justiça" ${ }^{157}$. Eram homens de consciência que defendiam a causa da Pátria, estando todos disciplinados pelo mesmo pensamento e pela mesma fé ${ }^{158}$. Votar nos republicanos seria proclamar a emancipação política, sendo que todas as instituições e os homens que as serviam tinham o direito de ser livres e que compreendessem "o terrível dilema: ou pela monarquia que nos perde ou pela República que nos salva! [...] não afrouxar no combate. Guerra ao regime, sem tréguas nem cartel" ${ }^{159}$. A tirania sufocava a maioria dos portugueses e a República era vista como a única salvação do patriotismo ${ }^{160}$. Do mesmo modo, as festas republicanas diferiam das monárquicas por serem sinceras, alegres, sem que para isso houvesse uma simples insinuação ${ }^{161}$.

Sem embargo, os republicanos consideravam que a transição de um regime político, através de um movimento revolucionário, originaria um período ditatorial. Não bastava influenciar a população com as novas ideias liberais, mas promover a continuação do movimento revolucionário, comparando-a com o papel do alfaiate:

Toma o alfaiate uma peça de pano, corta-a e recorta-a para fazer um fato, se deixa de a coser e servir convenientemente, adaptando as peças, fica apenas um montão de farrapos, para vestir bem o país, preciso é que a obra seja talhada a propósito e que depois seja entregue a artistas que a ponham à moda, tudo remodelado: ideias, costumes e... com gente nova ${ }^{162}$.

\footnotetext{
152 “A Nossa Propaganda”. Gazeta de Espinho, n. ${ }^{\circ} 377,05.04 .1908$, p. 1.

153 “A proclamação da República - Em Espinho”. Gazeta de Espinho, n. ${ }^{\circ}$ 508, 09.101910, p. 1-2.

154 “Desabafando...". Gazeta de Espinho, n. ${ }^{\circ} 369,09.02 .1908$, p. 1.

155 “A Nossa Propaganda”. Gazeta de Espinho, n. 377, 05.04.1908, p. 1.

156 "Desabafando...". Gazeta de Espinho, n. ${ }^{\circ} 369,09.02 .1908$, p. 1.

157 “Republicanos d'Espinho". Gazeta de Espinho, n. ${ }^{\circ}$ 406, 25.10.1908, p. 1.

158 “Eleitores, à urna pelos candidatos republicanos". Gazeta de Espinho, n. ${ }^{\circ}$ 502, 28.08.1910, p. 2.

${ }^{159}$ Idem.

160 “Desabafando". Gazeta de Espinho, n. ${ }^{\circ} 369,09.02 .1908$, p. 1.

161 “A proclamação da República - Em Espinho". Gazeta de Espinho, n. ${ }^{\circ}$ 508, 09.10.1910, p. 1-2.

162 "Revolução e ditadura”. Gazeta de Espinho, n. ${ }^{\circ} 366,19.01 .1910$, p. 1-2.
} 


\section{Conclusão}

Após a recolha e o tratamento da informação foi possível analisar a evolução do republicanismo em Espinho, entre 1908 e 1910.

Os republicanos organizavam-se em Comissões, realizando eleições para os cargos do partido. Optavam pela divulgação dos convites, conferências, comícios e homenagens, nos principais hotéis de Espinho, para propagandear a sua doutrina, e reuniam-se na Escola António José de Almeida para tratarem de assuntos eleitorais. Por outro lado, nas eleições municipais e paroquiais de 1908, os republicanos participaram com o objetivo de obterem o número máximo de votos, concorrendo com uma lista única e "independente". Em 1910, a instauração da República foi recebida com grande entusiasmo pelos populares. A transição do poder municipal foi feita de forma pacífica e os membros da Comissão Administrativa assumiram, rapidamente, um conjunto de decisões. Através da Gazeta de Espinho, os republicanos propagavam constantes críticas aos poderes monárquicos, exaltando as vantagens da República.

De uma maneira geral, os resultados da nossa pesquisa permitiram confirmar e aprofundar alguns aspetos essenciais do Estado da Arte. Embora houvesse pouca informação, quer nas fontes, quer na bibliografia, sobre as figuras ilustres de Espinho, foi possível compreender, sobretudo, a influência de Joaquim Pinto Coelho, Bessa de Carvalho e Manuel Laranjeira como principais militantes do Partido Republicano, em Espinho. Em relação à ação de Joaquim Pinto Coelho como «rosto» da oposição ao «Grupo da Fábrica», a fonte hemerográfica apresenta, exclusivamente, a opinião e a crítica do republicano à formação da nova coligação monárquica e a necessidade de criar unidades harmoniosas para combater a sua influência. Para além disso, ao contrário das eleições municipais, o periódico não expõe a maioria do número de votos obtidos pelos candidatos monárquicos nas eleições paroquiais. Em contrapartida, a descrição da instauração da República e da mudança do poder municipal para a Comissão Municipal Republicana, bem como as suas principais preocupações políticas, foram expostas simplificadamente.

A Gazeta de Espinho, órgão oficial do Partido Republicano Português no concelho, não prestava muita atenção aos partidos monárquicos e, como tal, as constantes críticas feitas aos poderes instituídos devem ser entendidas como forma de propaganda. A representação feita do Rei e da Casa Real é praticamente inexistente no período analisado e não foi encontrada informação suficiente para explorar o impacto do republicanismo nas várias freguesias do concelho de Espinho. 
Mais se adianta que alguns objetivos ficaram por se realizar, tendo em conta a atual situação pandémica do coronavírus SARS-CoV-2. Perante as dificuldades encontradas, a esperança é, espera-se, de prosseguir com a investigação, recorrendo à análise de um período mais longo à luz da Gazeta de Espinho e de outras fontes que permitirão verificar - e contradizer - as informações contidas no órgão oficial do Partido Republicano Português, em Espinho.

\section{Fontes}

\section{Fontes hemerográficas}

Gazeta de Espinho. Espinho, 1908-1910.

\section{Fontes arquivistas}

Arquivo Municipal de Espinho - Atas da Câmara Municipal de Espinho, 1910.

\section{Bibliografia}

ALMEIDA, Pedro Tavares - Legislação Eleitoral Portuguesa - 1820-1926. Lisboa: Imprensa Nacional, 1998.

AMORIM, Ana Patrícia Cordeiro de Sousa - Exposição - Rostos da República. No âmbito das comemorações do Centenário da República em Espinho. Porto: FLUP, 2010. Relatório de Estágio de Mestrado em História da Arte.

BRANDÃO, Francisco Azevedo - Anais da História de Espinho (985-1926). Espinho: CME/JFE, 1991.

GAIO, Carlos Morais - A Génese de Espinho. Histórias e Postais. Porto: Campo das Letras, 1999. LOPES, António Teixeira - O Nascimento de um Aglomerado Urbano: Espinho no Limiar do Século XX. Porto: FLUP, 1998. Dissertação de Mestrado em História Contemporânea. MARQUES, A. H. de Oliveira (coord.) - "Portugal da Monarquia para a República". In SERRÃO, Joel; MARQUES, A. H. de Oliveira (dir.) - Nova História de Portugal. Vol. XI. Lisboa: Editorial Presença, 1991.

MARQUES, A. H. de Oliveira (coord.) - Parlamentares e Ministros da 1. ${ }^{a}$ República (19101926). Lisboa: Assembleia da República, 2000.

RAMOS, Rui (coord.) - “A Segunda Fundação”. In MATTOSO, José (dir.) — História de Portugal, vol. 6. Lisboa: Editorial Estampa, 1997.

ROSAS, Fernando; ROLLO, Maria Fernanda (coord.) — História da Primeira República portuguesa. Lisboa: Tinta-da-china, 2009.

SERRÃO, Joaquim Veríssimo - “O fim da Monarquia”. In SERRÃO, Joaquim Veríssimo História de Portugal, vol. X. Lisboa: Editorial Verbo, 1988.

TELO, António José - Primeira República I - Do sonho à realidade. Lisboa: Editorial Presença, 2010.

VALENTE, Vasco Pulido - O poder e o povo: a revolução de 1910. Lisboa: Gradiva, 1999. 